J. Dairy Sci. 100:8161-8164

https://doi.org/10.3168/jds.2017-13146

Crown Copyright @ 2017. Published by FASS and Elsevier Inc. on behalf

of the American Dairy Science Association ${ }^{\circledR}$. All rights reserved.

\title{
Short communication: Apparent ruminal synthesis of B vitamins in lactating dairy cows fed Saccharomyces cerevisiae fermentation product
}

\author{
D. S. Castagnino, ${ }^{*} \dagger^{1}$ Y. Ying, $\ddagger^{2}$ M. S. Allen, $\ddagger$ R. Gervais, $\dagger$ P. Y. Chouinard,$\dagger$ and C. L. Girard ${ }^{* 3}$ \\ ${ }^{*}$ Agriculture and Agri-Food Canada, Sherbrooke Research and Development Centre, 2000 College, Sherbrooke, QC, Canada, J1M 0C8 \\ †Département des Sciences Animales, Université Laval, 2425 rue de l'Agriculture, Québec, QC, Canada, G1V 0A6 \\ ‡Department of Animal Science, Michigan State University, East Lansing 48824-1225
}

\begin{abstract}
Apparent ruminal synthesis and duodenal flow of thiamin, riboflavin, niacin, vitamin $\mathrm{B}_{6}$, folates, and vitamin $\mathrm{B}_{12}$ were evaluated in an experiment using 15 ruminally and duodenally cannulated lactating Holstein cows fed a basal diet, according to a crossover design, supplemented or not with $56 \mathrm{~g} / \mathrm{d}$ of Saccharomyces cerevisiae fermentation product. Duration of the treatment period was $28 \mathrm{~d}$. The basal ration had $28 \%$ neutral detergent fber, $30 \%$ starch and $16.5 \%$ crude protein; forages were corn silage $(67 \%$ of forage dry matter) and alfalfa silage (33\% of forage dry matter). Concentrations of B vitamins were analyzed in feed and duodenal digesta. Apparent ruminal synthesis of each $B$ vitamin was calculated as the duodenal flow minus the intake. Under the present experimental conditions, a dietary supplement of Saccharomyces cerevisiae fermentation product had no effect apparent synthesis of $\mathrm{B}$ vitamins in the rumen or on the amounts of these vitamins reaching the duodenum and available for absorption by the dairy cow.
\end{abstract}

Key words: dairy cow, B vitamin, Saccharomyces cerevisiae fermentation product, duodenal flow

\section{Short Communication}

According to a meta-analysis, feeding Saccharomyces cerevisiae fermentation products (SCFP) increases milk, protein, and fat yields of dairy cows; the supplement increases DMI when fed in early lactation, whereas it decreases it during late lactation (Poppy et al.,

\footnotetext{
Received May 11, 2017.

Accepted June 30, 2017.

${ }^{1}$ Current address: Centre for Nutrition Modelling, Department of Animal and Poultry Science, University of Guelph, 50 Stone Road East, Guelph, ON, Canada, N1G 2W1.

${ }^{2}$ Current address: Department of Medicine, Penn Center for Pulmonary Biology, Penn Cardiovascular Institute, University of Pennsylvania, Philadelphia, PA 19104-5159.

${ }^{3}$ Corresponding author: Christiane.Girard@agr.gc.ca
}

2012). Moreover, a SCFP supplement increases milk fat content (Li et al., 2016) or yield (Longuski et al., 2009) in cows fed highly fermentable diets, but not in cows fed less fermentable diets. It has been proposed that the effects of SCFP on production performance were due to modifications of rumen microbiota activity, such as an increase in microbial protein synthesis (Hristov et al., 2010), preferential growth of proteolytic (Wiedmeier et al., 1987; Yoon and Stern, 1996), or fiber-digesting (Wiedmeier et al., 1987) bacterial populations. Requirements of individual B vitamins differ among rumen bacteria populations (Scott and Dehority, 1965), affecting the amounts of vitamins available for the host. Consequently, the objective of the present project was to verify if feeding SCFP could change apparent ruminal synthesis (ARS) and duodenal flow (DF) of individual B vitamins in dairy cows.

Feed and duodenal digesta samples were collected during a research project conducted at Michigan State University following approval by the Institutional Animal Care and Use Committee (Allen and Ying, 2012). Fifteen multiparous Holstein cows from the Michigan State University Dairy Cattle Teaching and Research Center (East Lansing, MI), equipped with rumen and duodenal cannulas and housed in a tiestall facility, were used in this study. Animals were randomly assigned at $169(\mathrm{SD}=84)$ DIM to treatment sequences in a crossover design, with 28 -d treatment periods after a 14-d preliminary period when voluntary DMI was recorded. During preliminary and experimental periods, cows were offered the basal ration as TMR once daily at $110 \%$ of expected intake. The 2 treatments were the basal ration without $(\mathbf{C O N})$ or with $\mathrm{SCFP}(56 \mathrm{~g} / \mathrm{d}$; Diamond V XP Yeast Culture, Diamond V Mills Inc., Cedar Rapids, IA). The forage-to-concentrate ratio (\% of DM) was 56:44; forages were corn (67\% of forage DM) and alfalfa (33\% of forage DM) silages (Table 1). Individual feed intake was recorded daily. Samples of all feed ingredients were collected daily from d 21 to 25 during each experimental period and pooled by period. Duodenal samples were collected every $15 \mathrm{~h}$ from d 
Table 1. Ingredients, chemical composition and B-vitamin concentrations of the basal ration ${ }^{1}$

\begin{tabular}{lc}
\hline Composition & Value \\
\hline Ingredient, \% of DM & \\
Corn silage & 37.1 \\
Alfalfa silage & 18.6 \\
High-moisture corn & 23.5 \\
Soybean meal (48\% CP) & 10.8 \\
SoyPlus ${ }^{2}$ & 5.0 \\
Mineral-vitamin mix ${ }^{3}$ & 4.1 \\
Limestone & 1.0 \\
Chemical composition & \\
DM, \% as fed & 49.6 \\
OM, \% of DM & 92.6 \\
NDF, \% of DM & 28.0 \\
Forage NDF, \% of DM & 23.6 \\
Forage NDF, \% of NDF & 84.3 \\
Indigestible NDF, \% of DM & 11.6 \\
Indigestible NDF, \% of NDF & 41.4 \\
CP, \% of DM & 16.5 \\
Starch, \% of DM & 30.1 \\
Total cobalt, mg/kg of DM & 1.35 \\
B-vitamin concentrations, mg/kg of DM & \\
Thiamin & 1.10 \\
Riboflavin & 29.07 \\
Niacin & \\
Vitamin B ${ }_{6}{ }^{4}$ & 16.60 \\
Folates & 7.98 \\
Vitamin B ${ }_{12}$ & 0.69 \\
\hline & $\mathrm{ND}$ \\
\hline
\end{tabular}

\footnotetext{
${ }^{1}$ Adapted from Allen and Ying (2012).

${ }^{2}$ West Central Soy (Ralston, IA).

${ }^{3}$ Vitamin-mineral mix contained (DM basis) $17.6 \%$ sodium bicarbonate, $15.1 \%$ magnesium sulfate, $7.5 \%$ salt, $6.0 \%$ dicalcium phosphate $2.5 \%$ trace mineral premix, $0.4 \%$ vitamin $\mathrm{A}, 0.4 \%$ vitamin $\mathrm{D}, 0.2 \%$ vitamin $\mathrm{E}$, and $50.2 \%$ dry ground corn as a carrier.

${ }^{4}$ Sum of nicotinic acid and nicotinamide.

${ }^{5}$ Sum of pyridoxamine, pyridoxal, and pyridoxine.

${ }^{6} \mathrm{ND}=$ not detected
}

21 to 25 of each experimental period. The 8 samples collected were then pooled by cow and by period. All samples were stored at $-20^{\circ} \mathrm{C}$ before processing. Experimental procedures, measurements, and analyses were described by Allen and Ying (2012).

Concentrations of $\mathrm{B}$ vitamins in feed and duodenal digesta were analyzed at the Sherbrooke Research and Development Centre (Agriculture and Agri-Food
Canada, Sherbrooke, QC, Canada) as described by Castagnino et al. (2016a). Thiamin, riboflavin, niacin, and vitamin $\mathrm{B}_{6}$ were quantified by HPLC (Varian ProStar, Lake Forest, CA) equipped with a solvent delivery system (model 210), an autosampler (model 410), and a fluorescence detection system (model 363). Folates were determined with a microbiological microtiter plate test (VitaFast Folic Acid, R-Biopharm Inc., Marshall, $\mathrm{MI}$ ) and vitamin $\mathrm{B}_{12}$ was analyzed by radio-assay [SimulTRAC-S Vitamin $\mathrm{B}_{12}\left({ }^{57} \mathrm{Co}\right) /$ Folate $\left({ }^{125} \mathrm{I}\right)$, MP Biomedicals, Solon, OH]. Dietary Co concentrations were determined by atomic absorption spectrometry with flame stoichiometric air-acetylene at $240.7 \mathrm{~nm}$, as described by Castagnino et al. (2016b). Samples were analyzed in duplicate (except folates, for which samples were analyzed in triplicate), and a coefficient of variation of less than $10 \%$ was accepted between replicates.

Individual B-vitamin concentrations in the experimental TMR were the summation of each B-vitamin concentration in dietary ingredients (Table 2) multiplied by the proportion of these ingredients in the TMR, on a DM basis. Daily intakes of individual vitamins were calculated as the concentration of each vitamin in the TMR multiplied by cow DMI. Calculations of DM DF were described by Allen and Ying (2012). The duodenal flow of each B vitamin was calculated as B-vitamin concentrations in duodenal sample multiplied by the daily DM flowing through the duodenum. Apparent ruminal synthesis was calculated as DF minus the daily intake of each vitamin.

Daily intake, DF, and ARS for each vitamin, expressed in milligram per day or milligram per kilogram of DMI, were analyzed using the MIXED procedure of SAS (version 9.4; SAS Institute Inc., 2012), in which period and treatment were considered as fixed effects and cow as a random effect. Differences were declared significant at $P<0.05$ and as a tendency at $0.05 \leq P$ $\leq 0.10$

In the present experiment, DMI and DF did not differ between treatments $(P \geq 0.36)$; DMI and DF were 22.4 and $23.1(\mathrm{SE}=0.85) \mathrm{kg}$ of $\mathrm{DM} / \mathrm{d}$ and 16.4 and

Table 2. Concentrations of B vitamins $(\mathrm{mg} / \mathrm{kg}$ of $\mathrm{DM})$ for ingredients used in the basal ration $(\mathrm{mean} \pm \mathrm{SD} ; \mathrm{n}=2)$

\begin{tabular}{|c|c|c|c|c|c|c|}
\hline Item & Thiamin & Riboflavin & Niacin $^{1}$ & Vitamin $\mathrm{B}_{6}^{2}$ & Folates & Vitamin $\mathrm{B}_{12}$ \\
\hline Corn silage & $1.40 \pm 0.011$ & $33.21 \pm 2.462$ & $7.70 \pm 0.282$ & $17.39 \pm 0.785$ & $0.10 \pm 0.015$ & $\mathrm{ND}^{3}$ \\
\hline Alfalfa silage & $0.39 \pm 0.073$ & $50.25 \pm 6.045$ & $21.01 \pm 1.646$ & $10.35 \pm 4.424$ & $0.38 \pm 0.101$ & ND \\
\hline High-moisture corn & $0.64 \pm 0.020$ & $15.28 \pm 8.066$ & $11.92 \pm 2.852$ & $2.11 \pm 1.247$ & $0.07 \pm 0.013$ & ND \\
\hline Soybean meal (48\% CP) & $4.69 \pm 0.025$ & $12.47 \pm 1.190$ & $30.57 \pm 3.614$ & $3.08 \pm 0.495$ & $3.28 \pm 0.120$ & ND \\
\hline SoyPlus ${ }^{4}$ & $0.82 \pm 0.030$ & $19.36 \pm 0.857$ & $25.13 \pm 1.255$ & $1.67 \pm 0.148$ & $3.20 \pm 0.331$ & ND \\
\hline
\end{tabular}

\footnotetext{
${ }^{1}$ Sum of nicotinic acid and nicotinamide.

${ }^{2}$ Sum of pyridoxamine, pyridoxal, and pyridoxine.

${ }^{3} \mathrm{ND}=$ not detected.

${ }^{4}$ West Central Soy (Ralston, IA).
} 
Table 3. Intake of B vitamins (expressed in $\mathrm{mg} / \mathrm{d}$ ), duodenal flow and apparent ruminal synthesis (ARS; expressed as mg/d and as $\mathrm{mg} / \mathrm{kg}$ of $\mathrm{DMI}$ ) of cows fed Saccharomyces cerevisiae fermentation product (SCFP) or the basal control diet only (CON)

\begin{tabular}{|c|c|c|c|c|c|c|c|c|}
\hline \multirow[b]{2}{*}{ Vitamin } & \multicolumn{2}{|c|}{ Treatment LSM, mg/d } & \multirow[b]{2}{*}{ SEM } & \multirow[b]{2}{*}{$P$-value } & \multicolumn{2}{|c|}{ Treatment LSM, g/kg of DMI } & \multirow[b]{2}{*}{ SEM } & \multirow[b]{2}{*}{$P$-value } \\
\hline & $\mathrm{CON}$ & SCFP & & & $\mathrm{CON}$ & SCFP & & \\
\hline \multicolumn{9}{|l|}{ Thiamin } \\
\hline Intake & 24.7 & 25.4 & 0.95 & 0.40 & & & & \\
\hline Duodenal flow & 63.9 & 64.5 & 4.10 & 0.90 & 2.82 & 2.79 & 0.125 & 0.84 \\
\hline ARS & 39.2 & 39.1 & 3.44 & 0.97 & 1.71 & 1.68 & 0.125 & 0.84 \\
\hline \multicolumn{9}{|l|}{ Riboflavin } \\
\hline ARS & 232 & 235 & 32.0 & 0.90 & 10.19 & 10.03 & 1.229 & 0.90 \\
\hline \multicolumn{9}{|l|}{ Niacin $^{1}$} \\
\hline Intake & 373 & 383 & 14.4 & 0.47 & & & & \\
\hline Duodenal flow & 2,128 & 2,186 & 190.8 & 0.65 & 95.2 & 93.8 & 7.32 & 0.66 \\
\hline ARS & 1,756 & 1,804 & 184.2 & 0.68 & 78.6 & 77.2 & 7.33 & 0.66 \\
\hline \multicolumn{9}{|l|}{ Vitamin $\mathrm{B}_{6}{ }^{2}$} \\
\hline Intake & 178 & 183 & 7.40 & 0.53 & & & & \\
\hline ARS & 74.1 & 73.4 & 10.22 & 0.94 & 3.22 & 3.10 & 0.401 & 0.74 \\
\hline \multicolumn{9}{|l|}{ Vitamin $B_{12}$} \\
\hline Intake $^{3}$ & $\mathrm{ND}^{3}$ & ND & - & - & & & & \\
\hline Duodenal flow & 10.8 & 10.3 & 0.77 & 0.39 & 0.48 & 0.44 & 0.029 & 0.13 \\
\hline ARS & 10.8 & 10.3 & 0.77 & 0.39 & 0.48 & 0.44 & 0.029 & 0.13 \\
\hline
\end{tabular}

${ }^{1}$ Sum of nicotinic acid and nicotinamide.

${ }^{2}$ Sum of pyridoxamine, pyridoxal, and pyridoxine.

${ }^{3}$ Not detected.

$17.0(\mathrm{SE}=0.92) \mathrm{kg}$ of $\mathrm{DM} / \mathrm{d}$, for $\mathrm{CON}$ and SCFP, respectively. Intake of individual B vitamins was similar in basal diets for both treatments $(P \geq 0.36)$. Neither B-vitamin DF nor ARS, expressed in milligrams per day or in milligrams per kilogram of DM, were affected by $\operatorname{SCFP}(P \geq 0.13$; Table 3$)$.

Samples of SCFP were not available when the vitamin analyses were conducted. Based on the product Profile Sheet (https://store.buchanancellers.com/inet/ storefront/getpdf.php?recid=223), except for vitamin $\mathrm{B}_{12}$, the amount of individual $\mathrm{B}$ vitamins provided by $56 \mathrm{~g} / \mathrm{d}$ of SCFP would represent less than $2 \%$ of total daily intake of each vitamin from the basal diet. Nevertheless even if B-vitamin supply would have been greater for cows fed SCFP, the supplement had no effect on B-vitamin DF.

Production responses following SCFP supplementation vary according to DIM (Poppy et al., 2012) and dietary NDF concentrations (Robinson and Erasmus, 2009), and are likely explained by changes in fermentation and microbial populations in the rumen. In the present experiment, however, neither rumen fermentation, nor nutrient ruminal digestibility (Allen and Ying, 2012), nor the relative abundance of 12 ruminal microbial species (Mullins et al., 2013) differed between CON and SCFP. Using DMI recorded during the preliminary period as a covariable, Allen and Ying (2012) reported that SCFP increased the rate of starch digestion in the rumen of cows with lower DMI (DMI during the preliminary period below $26 \mathrm{~kg} / \mathrm{d}$ ), but had the opposite effect in cows with higher DMI. Nevertheless, even when conducting statistical analyses according to the model described by Allen and Ying (2012), neither treatment effects nor interactions between DMI during the preliminary period and treatment were significant for all the studied vitamins (data not shown). Consequently, under the present experimental conditions, where the SCFP supplement had no effect on the ruminal fermentation pattern (Allen and Ying, 2012; Mullins et al., 2013), it also had no effect on B-vitamin supply for the dairy cows.

\section{ACKNOWLEDGMENTS}

The authors thank Chrystiane Plante and Valérie Beaudet (Sherbrooke Research and Development Centre, Agriculture and Agri-Food Canada, Sherbrooke, QC, Canada) for their technical support. Vitamin analyses were financially supported by the Programme de recherche en partenariat pour l'innovation en production et transformation laitière Novalait - Agriculture et Agroalimentaire Canada - Fonds de recherche du Qué- 
bec Nature et Technologies - Ministère de l'Agriculture, des Pêcheries et de l'Alimentation du Québec, Québec, QC, Canada.

\section{REFERENCES}

Allen, M. S., and Y. Ying. 2012. Effects of Saccharomyces cerevisiae fermentation product on ruminal starch digestion are dependent upon dry matter intake for lactating cows. J. Dairy Sci. 95:65916605. https://doi.org/10.3168/jds.2012-5377.

Castagnino, D. S., K. L. Kammes, M. S. Allen, R. Gervais, P. Y Chouinard, and C. L. Girard. 2016b. Particle length of silages affects apparent ruminal synthesis of B vitamins in lactating dairy cows. J. Dairy Sci. 99:6229-6236. https://doi.org/10.3168/jds.2016 -11274 .

Castagnino, D. S., M. Seck, V. Beaudet, K. L. Kammes, J. A. Voelker Linton, M. S. Allen, R. Gervais, P. Y. Chouinard, and C. L. Girard. 2016a. Effects of forage family on apparent ruminal synthesis of B vitamins in lactating dairy cows. J. Dairy Sci. 99:1884-1894. https://doi.org/10.3168/jds.2015-10319.

Hristov, A. N., G. Varga, T. Cassidy, M. Long, K. Heyler, S. K. R. Karnati, B. Corl, C. J. Hovde, and I. Yoon. 2010. Effect of Saccharomyces cerevisiae fermentation product on ruminal fermentation and nutrient utilization in dairy cows. J. Dairy Sci. 93:682-692. https://doi.org/10.3168/jds.2009-2379.

Li, S., I. Yoon, M. Scott, E. Khafipour, and J. C. Plaizier. 2016. Impact of Saccharomyces cerevisiae fermentation product and subacute ruminal acidosis on production, inflammation, and fermentation in the rumen and hindgut of dairy cows. Anim. Feed Sci. Technol. 211:50-60. https://doi.org/10.1016/j.anifeedsci.2015.10.010.
Longuski, R. A., Y. Ying, and M. S. Allen. 2009. Yeast culture supplementation prevented milk fat depression by a short-term dietary challenge with fermentable starch. J. Dairy Sci. 92:160-167. https://doi.org/10.3168/jds.2008-0990.

Mullins, C. R., L. K. Mamedova, A. J. Carpenter, Y. Ying, M. S. Allen, I. Yoon, and B. J. Bradford. 2013. Analysis of rumen microbial populations in lactating dairy cattle fed diets varying in carbohydrate profiles and Saccharomyces cerevisiae fermentation product. J. Dairy Sci. 96:5872-5881. https://doi.org/10.3168/jds .2013-6775.

Poppy, G. D.. A. R. Rabiee, I. J. Lean, W. K. Sanchez, K. L. Dorton, and P. S. Morley. 2012. A meta-analysis of the effects of feeding yeast culture produced by anaerobic fermentation of Saccharomyces cerevisiae on milk production of lactating dairy cows. J. Dairy Sci. 95:6027-6041. https://doi.org/10.3168/jds.2012-5577.

Robinson, P. H., and L. J. Erasmus. 2009. Effects of analyzable diet components on responses of lactating dairy cows to Saccharomyces cerevisiae based yeast products: A systematic review of literature. Anim. Feed Sci. Technol. 149:185-198. https://doi.org/10.1016/j anifeedsci.2008.10.003.

SAS Institute Inc. 2012. User's Guide: Statistics. Version 9.4. SAS Institute Inc., Cary, NC.

Scott, H. W., and B. A. Dehority. 1965. Vitamin requirements of several cellulolytic rumen bacteria. J. Bacteriol. 89:1169-1175.

Wiedmeier, R. D., M. J. Arambel, and J. L. Walters. 1987. Effect of yeast culture and Aspergillus oryzae fermentation extract on ruminal characteristics and nutrient digestibility. J. Dairy Sci. 70:20632068. https://doi.org/10.3168/jds.S0022-0302(87)80254-0.

Yoon, I. K., and M. D. Stern. 1996. Effects of Saccharomyces cerevisiae and Aspergillus oryzae cultures on ruminal fermentation in dairy cows. J. Dairy Sci. 79:411-417. https://doi.org/10.3168/jds.S0022 -0302(96)76380-4. 